\title{
Six Sigma Sebagai Strategi Bisnis Dalam Upaya Peningkatan Kualitas Produk
}

Jurnal Akuntansi Terapan Indonesia Vol 3 No 1 Hal 1-14 March 2020

Affiliation:

Universitas Trilogi, Indonesia

*Correspondence:

srimurnifitria96@gmail.com

This Article is Avalilable in: https://journal.umy.ac.id/index. php/jati/article/view/8385

DOI:

10.18196/jati.030121

Citation:

Fitria, S. (2020). Six Sigma Sebagai Strategi Bisnis Dalam Upaya Peningkatan Kualitas Produk. Jati: Jurnal Akuntansi Terapan Indonesia, 3(1), 1-14

\section{Article History}

Received:

03 February 2020

Reviewed :

04 March 2020

Revised :

11 March 2020

Accepted:

31 March 2020

Topic Article:

Financial Accounting

\author{
Sri Murni Fitria*1, Novita ${ }^{2}$
}

\begin{abstract}
:
A company should have the right strategy to survive and compete with local and international competitors. One strategy to improving product quality is six sigma. This study aim to figure out how the strategy improving product quality using six sigma. Gathering data through observation, documentation and interview. Analyzing data through DMAIC methodology (Define, Measure, Analyze, fImprove, Control). In this study known that the3object ofacompany is uncompetitive because the result is at level of 2,7 with DPMO value is $106.416,66$. It means that while in production process, there are many products that are not suitable with what consumer want . there are some suggestions to fix it and to control it by result control, action control, personel control and culture control.
\end{abstract}

Keywords: Six Sigma, Quality Management, Quality Control

\section{Abstrak:}

Suatu perusahaan harus memiliki strategi yang tepat agar mampu bertahan dan bersaing dengan para competitor yang ada baik dalam negeri maupun luar negeri. Maka salah satu strategi yang dapat dilakukan yaitu dengan meningkatkan kualitas produk menggunakan six sigma. Pengumpulan data yang dilakukan yaitu melalui observasi,dokumentasi, dan wawancara. Analisis data melalui metodologi DMAIC (Define, Measure, Analyze,Improve, Control). Dalam penelitian ini diketahui bahwa perusahaan yang menjadi objek penelitian tersebut sangat tidak kompetitif karena berada pada level sigma 2.7 dengan nilai DPMO sebesar 106.416,66. Hal ini menunjukkan bahwa dalam proses produksi yang dilakukan masih banyak produk yang tidak sesuai dengan keinginan konsumen. Ada beberapa usulan perbaikan serta pengendalian yang dapat dilakukan yaitu dengan melakukan pengendalian hasil (result control), pengendalian tindakan (action control), pengendalian personel (personel control) dan pengendalian budaya (culture control).

Kata Kunci: Six Sigma, Manajemen Kualitas, Pengendalian Kualitas

\section{PENDAHULUAN}

Industri sektor manufaktur merupakan salah satu sektor industri yang semakin meningkat dari tahun ke tahun salah satunya yaitu industri tekstil dan garment. Industri tersebut pada saat ini menjadi industry yang sangat tepat bagi perekonomian Indonesia bahkan industri tekstil dan garment menjadi sektor manufaktur terbesar ketiga di Indonesia. Pada tahun 2019 ketua Asosiasi Pertekstilan Indonesia Ade Sudrajat Usman mengungkapkan bahwa industri garment \& tekstil terutama dari sektor ekspor akan tumbuh sebesar $7 \%$ dengan $6 \%$ ditunjang oleh sector ekspor (Kontan.co.id, 2019). Semakin luasnya jangkauan pasar dan ketatnya persaingan agar mampu bertahan dan bersaing dengan kompetitor perusahaan harus memiliki strategi 
yang tepat yaitu melakukan peningkatan kualitas dari setiap produk yang dihasilkan. Manajemen kuliatas merupakan suatu cara yang bertujuan untuk meningkatkan kinerja secara terus-menerus pada setiap level operasi atau proses dalam setiap area fungsional dari suatu organisasi dengan menggunakan semua sumber daya manusia serta modal yang tersedia Gaspersz, (2011). Kualitas menurut Goetsch dan Davis (dalam Widiatmoko \& Segoro, 2015) adalah kondisi atau keadaan yang dinamis terhadap suatu produk seperti jasa orang proses dan lingkungan yang sesuai atau bahkan mampu melebihi harapan pelanggan yang menciptakan nilai produk yang superior.

Menurut Damayanti, (2017) ada beberapa metode pendekatan yang selama ini digunakan untuk menjamin sebuah kualitas standar diantaranya TQM (Total Quality Management) $\mathrm{Cl}$ (Continous Improvement) Kaizen Process Re Engineering Failure Mode and Effect Analysis Design Reviews Voice of the Costumer Cost of Quality (COQ) memiliki tingkat keberhasilan yang bervariasi bahkan $80 \%$ implementasi dari TQM mengalami kegagalan di masa lampau. Oleh karena itu sudah saatnya perusahaan harus memahami bahwa kualitas tidak harus mengeluarkan biaya yang tinggi melainkan proses yang lebih efisien dan andal dalam menghasilkan output yang bebas cacat (zero defect). Perusahaan harus berfokus pada perbaikan proses dan kepuasan pelanggan hal itu dapat dilakukan melalui pendekatan six sigma. Six sigma merupakan sebuah konsep statistik yang mengukur proses-proses yang berkaitan dengan cacat pada level enam (six) sigma yaitu hanya ada 3,4 cacat dari sejuta peluang Sirine et al., (2017). Serta six sigma juga dapat digunakan untuk mengidentifikasi dan kemudian mengeliminasi kegagalan atau kesalahan yang mungkin dapat berakibat pada suatu proses produksi Nakhai \& Neves, (2009).

Banyak para peneliti yang telah mengembangkan metode six sigma dengan berbagai pendekatan yang dilakukan. F. Hutami \& Yunitasari (2017) mengkaji bahwa PT.Okantara yang bergerak dibidang industri percetakan melalui metode six sigma diketahui belum sepenuhnya mampu mengendalikan kualitas produk. Alfian huda (2018) melalui pendekatan dengan metode six sigma maka terindikasi bahwa PT. XYZ belum mampu mengendalikan kualitas dan yang menjadi faktor penyebab produk cacat yaitu faktor metode dan faktor material. Safrizal \& Muhajir (2016) menyatakan bahwa melalui metode six sigma dapat diketahui bahwa pengendalian kualitas belum maksimal atau masih tinggi.Sirine et al (2017) Menyimpulkan bahwa perusahaan telah mencapai six sigma yang berarti perusahaan tersebut benar-benar telah melakukan control kualitas yang sangat baik.

Jirasukprasert (2015) mengkaji bahwa melalui penerapan prinsip six sigma dengan DMAIC berhasil mengurangi cacat six sigma dan DMAIC menjadi metodologi dalam pemecahan masalah. Dalam penelitian tersebut juga diyakini bahwa melalui prinsip six sigma dan DMAIC banyak sekali manfaat yang diperoleh seperti penghematan biaya peningkatan kualitas produk sehingga dapat mencapai kepuasan pelanggan. Antony (2016) mengkaji bahwa six sigma lebih jarang digunakan. Dalam proyek dan penyelidikan lebih lanjut telah menunjukkan bahwa perusahaan studi kasus tersebut menggunakan eksperimen taguchi untuk karakterisasi dan proses optimalisasi. Mijajlevski (2013) dengan six sigma dapat diketahui variasi cacat dan menemukan solusi untuk menghilangkan cacat dan kemungkinan dapat mencapai "Zero Defect". Wulandari (2018) mengkaji bahwa dengan penerapan metode six sigma dapat diketahui faktor-faktor penyebab produk cacat, jenis-jenis cacat dan meningkatkan kinerja dari perusahaan.

Perusahaan manufaktur yang akan menjadi objek penelitian adalah konveksi Cindy Garment dimana perusahaan ini memproduksi pakaian jadi berupa baju kaos. Dalam proses produksinya selalu menemukan produk cacat atau kerusakan pada output yang dihasilkan sehingga kecil sekali kemungkinan untuk menghasilkan produk yang sempurna. Hal itu dapat merusak kinerja dari perusahaan bahkan dapat mengurangi pendapatan dari perusahaan tersebut diketahui dalam laporan produksi pada konveksi Cindy Garment dari bulan Februari - April 2018 dimana setiap minggu jumlah cacat (defect) produk yang dihasilkan berfluktuasi. 
Selama periode Februari sampai April 2018 jumlah produk cacat sebanyak 655 dari 6.121 jumlah produksi kaos oblong dari konveksi Cindy garment dengan rata-rata produk cacat $54,5 \%$.

Hal itu tentu sangat merugikan perusahaan maka dari itu peningkatan kualitas sangat penting sehingga perlu dilakukan penelitian apakah dengan menggunakan six sigma mampu meningkatkan kualitas produk sesuai dengan standarisasi yang diinginkan oleh perusahaan. Maka penelitian ini mengangkat judul "Six Sigma Sebagai Strategi Bisnis dalam Upaya Peningkatan Kualitas Produk". Sehingga dengan adanya penelitian ini dapat membantu perusahaan untuk menekan tingkat kecacatan produk serta pemborosan dalam proses produksi. Melalui penelitian ini perusahaan dapat mengetahui jenis cacat potensial, faktor penyebab cacat serta mengetahui strategi perbaikan yang akan dilakukan untuk masa mendatang.

\section{METODE PENELITIAN}

Menurut Sugiyono,(2016) analisis data dalam penelitian kualitatif dilakukan sebelum memasuki lapangan selama di lapangan dan setelah selesai di lapangan. Miles and Huberman (dalam Sugiyono, 2016) mengemukakan bahwa aktivitas dalam analisis data kualitatif dilakukan secara interaktif dan berlangsung terus menerus sampai tuntas dan datanya sudah jenuh. Dalam penelitian ini analisis data yang digunakan yaitu melalui metodologi DMAIC (Define, Measure, Analyze, Improve, Control).

Define

Proses identifikasi masalah yang akan terhadi pada perusahaan hal ini dilakukan untuk mengetahui apakah permasalahan yang ada dalam penelitian telah terjadi di perusahaan tersebut menetapkan masalah yang menajdi objek penelitian menjelaskan tentang proses produksi mendeskripsikan Critical To Quality (CTQ) serta menggunakan SIPOC diagram untuk mengetahui proses produksi.

\section{Measure}

Pada tahap measure yang dilakukan ialah mengetahui tingkat sigma atau level sigma yang dicapai oleh perusahaan maka untuk mengetahui tingkat sigma tersebut yang dilakukan pada tahap measure yaitu menghitung nilai Defect Per Unit (DPU) Defect Per Million Opportunities (DPMO) dan melakukan konversi sigma, agar dapat melihat tingkat sigma yang dicapai oleh perusahaan. Berikut adalah rumus yang digunakan:

$$
\begin{aligned}
& \text { Defect per Unit (DPU) } \\
& \qquad D P U=\frac{\text { Jumlah kerusakan }}{\text { Jumlah produksi }} \\
& \text { Defect per Million } \begin{array}{l}
\text { Opportunities (DPMO) } \\
\text { DPMO }=\text { DPU X 1000.000 }
\end{array}
\end{aligned}
$$

Setelah mengetahui tingkat sigma yang dicapai maka yang dilakukan selanjutnya yaitu membuat pareto chart dan peta kendali (control chart).

\section{Analyze}

Analize merupakan langkah ketiga dalam program peningkatan kualitas dengan metode six sigma. Pada tahap analyze yang dilakukan dalam penelitian ini ialah mencari faktor penyebab dari permasalahan yang terjadi hal itu dilakukan dengan menggunakan fishbone diagram atau yang disebut dengan diagram sebab akibat. 
Improve

Pada tahapan ini ialah tahap memberikan masukan serta usulan perbaikan kepada perusahaan tentang masalah kecacatan produk yang terjadi pada perusahaan tersebut. Hal ini dilakukan agar perusahaan mampu menekan atau meminimalisir tingkat kecacatan produk sesuai dengan tujuan serta manfaat dari penelitian yang akan dicapai.

Control

Control ialah memastikan level baru kinerja dalam kondisi standar dan terjaga nilainilai peningkatannya yang kemudian didokumentasikan dan disebarluaskan dengan tujuan sebagai langkah perbaikan untuk kinerja proses berikutnya.

\section{HASIL DAN PEMBAHASAN}

Berdasarkan SIPOC diagram alur proses yang dilakukan tergambar jelas dari awal proses sampai akhir proses. Ada empat jenis cacat yang terjadi yaitu sablon rusak, noda bahan, serat bahan dan bahan bolong. Perusahaan berada pada level sigma 2,7 dengan DPMO sebesar $106,415,66$ hal ini menunjukkan perusahaan sangat tidak kompetitif walaupun pada peta kendali (control chart) proses produksi yang dilakukan berada pada batas toleran dimana proses produksi yang dilakukan stabil tetapi produk cacat terus terjadi dan berfluktuasi. Faktor-faktor penyebab dari kerusakan (defect) yaitu manusia, material, metode dan lingkungan. Oleh karena itu ada beberapa usulan perbaikan yang dapat dilakukan. Berikut adalah penjelasan mulai dari tahap define, measure, analyze, improve dan control.

Mendefinisikan merupakan tahap awal yang dilakukan dalam six sigma hal pertama yang harus dilakukan oleh perusahaan yaitu menentukan masalah-masalah atau hambatan yang terjadi dalam perusahaan. Dimana setiap perusahaan harus dapat mengetahui dan memahami permasalahan yang terjadi dalam perusahaan tersebut karena besar atau kecilnya masalah yang terjadi hal itu dapat menghambat perusahaan dalam mencapai tujuan (goals) yang diinginkan. Pada tahap ini perusahaan mendefinisikan dan menyeleksi permasalahan yang akan diselesaikan serta mengetahui manfaat dan dampak permasalahan tersebut terhadap konsumen. Maka dalam langkah define hal pertama yang harus dilakukan dalam penelitian ini agar dapat menemukan masalah-masalah yang terjadi pada konveksi Cindy Garment yaitu mendefinisikan kegiatan produksi serta mendefinisikan proses-proses kunci atau alur proses dari produksi baju kaos oleh konveksi Cindy Garment dengan menggunakan SIPOC diagram.

Berikut adalah penjelasan dari diagram SIPOC (supplier input process output customers) pada konveksi Cindy Garment.

\section{Supplier}

Supplier merupakan suatu perusahaan yang menyuplai kebutuhan proses produksi. Supplier sangat penting bagi perusahaan karena dengan adanya supplier hal itu sangat membantu perusahaan dalam memenuhi kebutuhan produksi serta harga yang diperoleh dari supplier juga lebih terjangkau. Pada konveksi Cindy Garment dalam proses produksi baju kaos ada beberapa supplier yang menyuplai bahan baku (direct material) dan bahan penolong (indirect material) yang dibutuhkan oleh konveksi Cindy Garment. Beberapa supplier tersebut yaitu Toko Murah Rezeki dimana toko tersebut memberikan pasokan seperti benang plastik karton dan bahan penolong lainnya kemudian selain Toko Murah Rezeki ada Toko Samudra Toko Budi Tekstil dan Toko Tekstil Suryadi yang menjadi pemasok bahan atau kain untuk pembuatan baju kaos. Selain itu ada Toko Benang Warna dan Mustika Jaya sebagai pemasok bahan penolong lain seperti minyak mesin jarum serta keperluan jahit lainnya. 
Fitria, Novita

Six Sigma Sebagai Strategi Bisnis Dalam Upaya Peningkatan Kualitas Produk

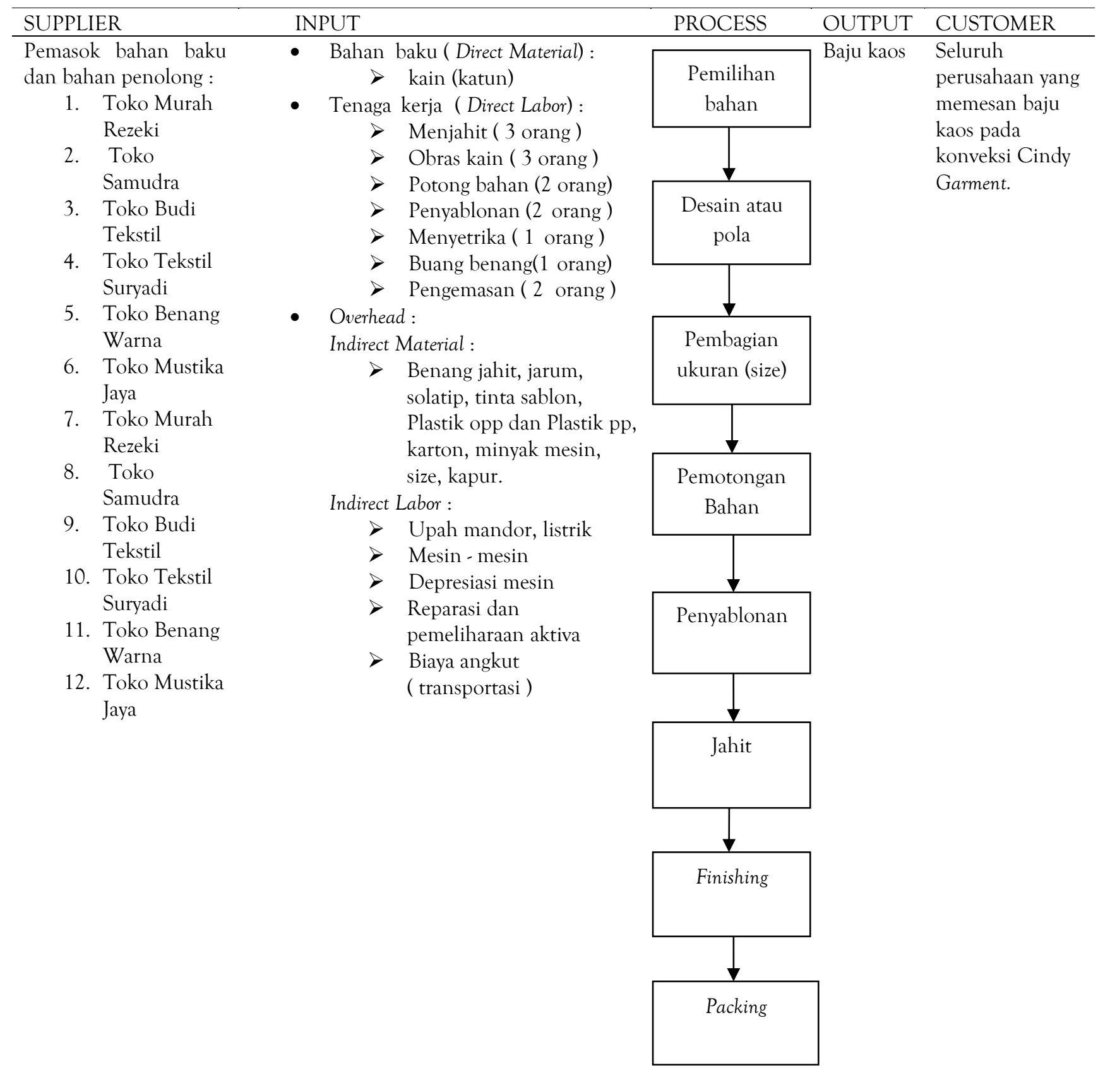

Gambar 1. SIPOC diagram

Sumber: Konveksi Cindy Garment (2019)

Input

Untuk menghasilkan suatu output ada beberapa sumber daya yang akan dibutuhkan oleh perusahaan. Dalam proses produksi yang dilakukan oleh perusahaan manufaktur seperti yang akan dilakukan oleh konveksi Cindy Garment input tersebut diklasifikasikan atau dikelompokkan menjadi bahan baku langsung (direct material) tenaga kerja langsung (direct labor) dan overhead dimana overhead terbagi atas dua jenis yaitu indirect material dan indirect labor semua jenis sumber daya tersebut termasuk ke dalam biaya produksi. 


\section{Process}

Process merupakan kegiatan yang dilakukan untuk mengelola input agar dapat memberikan nilai tambah atau value bagi perusahaan sehingga dapat menjadi suatu output yang diinginkan oleh konsumen. Process tersebut harus dilakukan dengan teliti dan hati-hati mulai dari awal process sampai akhir process. Ada beberapa alur process atau langkah-langkah yang dilakukan dalam membuat baju kaos pada konveksi Cindy Garment yaitu dengan melakukan pemilihan bahan terlebih dahulu kemudian membuat desain atau pola setelah itu membagi ukuran (size) kemudian melakukan pemotongan bahan penyablonan lalu bahan yang sudah dipotong dan di sablon disatukan dengan menjahit bahan atau kain tersebut. Setelah itu sampai ke tahap finishing dimana pada tahap finishing dilakukan pembuangan benang sekaligus memeriksa atau menyortir produk yang sudah jadi apakah produk tersebut selesai dengan kualitas yang baik atau buruk. Kemudian menyetrika atau menggosok baju kaos agar terlihat rapi setelah itu dilakukan pengemasan (packing) baju kaos tersebut dikemas menggunakan plastik opp dan plastik pp.

Output

Output merupakan suatu tujuan dari proses produksi yang dilakukan oleh perusahaan. Pada konveksi Cindy Garment setelah input melewati beberapa proses pengerjaan mulai dari awal proses produksi seperti pemilihan bahan dimana bahan yang dipilih oleh konveksi Cindy Garment adalah bahan cotton kemudian desain atau pola yang dapat dirancang oleh pemilik atau telah disediakan oleh konsumen. Ialu melakukan pembagian ukuran (size) dimana pembagian ukuran dilakukan sesuai dengan standar yang ada kemudian melakukan pemotongan bahan dengan mesin potong khusus bahan atau kain. Setelah itu melakukan penyablonan atau pembordiran sesuai dengan keinginan konsumen kemudian bahan yang telah di sablon dijahit sehingga berbentuk barang jadi kemudian dilakukan finishing seperti membuang benang sisa jahitan atau membersihkan dan melakukan pengecekan kesesuaian bentuk kemudian menggosok dan melakukan packing atau pengemasan. Maka akan menghasilkan output atau produk akhir yang diinginkan yaitu baju kaos yang memiliki kualitas sesuai dengan keinginan konsumen.

\section{Customers}

Customers merupakan pihak - pihak yang menggunakan hasil output dari proses produksi yang dilakukan oleh perusahaan pada SIPOC diagram customers merupakan tahapan terakhir dari proses - proses kunci yang telah terdapat pada SIPOC diagram. Dimana customers merupakan tujuan dari suatu bisnis atau perusahaan konveksi Cindy Garment memproduksi produk dengan sistem make to order dimana barang atau produk yang dibuat berdasarkan pesanan dari konsumen maka yang menjadi tujuan atau customers dari konveksi Cindy Garment adalah seluruh perusahaan atau pihak-pihak yang memesan baju kaos dengan memberikan merek dagang sendiri seperti perusahaan yang memiliki merek dagang NEVADA H\&R JM dan merek dagang lain.

Tabel 1. Critical To Quality

Sumber: Konveksi Cindy Garment (2019)

\begin{tabular}{lll}
\hline No & Jenis Cacat & Deskripsi \\
\hline 1 & Sablon rusak & Sablon luntur hasil cetakan sablon hilang \\
2 & Noda bahan & Bahan terkena makanan atau kotoran lain \\
3 & Bahan bolong & Terdapat kecacatan bahan berupa bolong \\
4 & Serat bahan & Serat pada bahan tidak terisi penuh (renggang) \\
\hline
\end{tabular}

Berdasarkan SIPOC diagram konveksi Cindy Garment mempunyai informasi yang jelas mengenai supplier input process output serta customer. Hal ini sejalan dengan penelitian 
terdahulu F. Hutami \& Yunitasari, (2017) yang mengungkapkan bahwa perusahaan dikatakan berkualitas apabila memiliki sistem produksi yang baik dengan proses yang terkendali salah satunya dengan memiliki penggambaran proses produksi yang jelas. Pada Tabel 1 pengidentifikasian CTQ diketahui bahwa ada empat jenis CTQ yaitu sablon rusak, noda bahan, bahan bolong serta serat bahan. Hal ini sesuai dengan penelitian terdahulu Sirine et al (2017) yang mengungkapkan bahwa yang dilakukan pada tahap define yaitu mendefinisikan proses kunci serta tanggapan pelanggan terhadap produk yang dihasilkan kemudian dibandingkan dengan standarisasi yang ditetapkan.

\section{Measure}

Langkah measure merupakan langkah yang dilakukan setelah langkah define dimana pada tahap measure mulai menyentuh fakta dan data-data atau angka-angka yang memberikan petunjuk mengenai akar dari permasalahan yang terjadi. Pada tahap measure yang dilakukan yaitu mengukur tingkat sigma serta menentukan defect per million opportunities (DPMO). Berikut adalah Tabel 2 pengukuran tingkat sigma dan defect per million opportunities (DPMO) periode Februari-April 2018

Tabel 2. Pengukuran tingkat sigma dan defect per million opportunities (DPMO) periode Februari-April 2018

Sumber: Laporan produksi konveksi baju kaos Cindy Garment 2018

\begin{tabular}{rccccl}
\hline Minggu & Jumlah & Jumlah & DPU & DPMO & Nilai \\
& Produksi & Cacat & & & Sigma \\
\hline 1 & 216 & 30 & 0,1389 & 138.900 & 2,5 \\
2 & 450 & 38 & 0,0844 & 84.400 & 2,875 \\
3 & 433 & 33 & 0,0762 & 76.200 & 2,875 \\
4 & 500 & 50 & 0,1 & 100.000 & 2,75 \\
5 & 348 & 36 & 0,1034 & 103.400 & 2,75 \\
6 & 444 & 42 & 0,0946 & 94.600 & 2,75 \\
7 & 552 & 50 & 0,0906 & 90.600 & 2,75 \\
8 & 594 & 70 & 0,1178 & 117.800 & 2,625 \\
9 & 613 & 52 & 0,0848 & 84.800 & 2,75 \\
10 & 629 & 79 & 0,1256 & 125.600 & 2.625 \\
11 & 654 & 85 & 0,1299 & 129.900 & 2,625 \\
12 & 688 & 90 & 0,1308 & 130.800 & 2,5 \\
Total & 6.121 & 655 & & & \\
Rata-rata & & & 0,1064166 & $106.416,66$ & 2,7 \\
\hline
\end{tabular}

Berdasarkan Tabel 2 diketahui bahwa konveksi Cindy Garment berada pada level sigma 2,7 dengan DPMO sebesar 106.416,66 yang berarti bahwa perusahaan masih membuangbuang uang dengan melakukan pekerjaan ulang (rework). Berada pada level sigma dua hal itu sangat tidak kompetitif bagi perusahaan karena jika semakin banyak kerusakan (defect) yang terjadi maka dapat berpengaruh pada pendapatan dan citra dari perusahaan. Jika suatu perusahaan berada pada level enam sigma hal itu jauh lebih baik karena semakin tinggi level sigma atau tingkat sigma yang mampu dicapai oleh perusahaan. Maka kualitas perusahaan sangat bagus dan mampu bersaing dengan perusahaan lain karena berada pada level enam sigma itu menunjukkan bahwa perusahaan berhasil mencapai zero defect atau hampir tidak ada cacat dalam proses produksi yang dilakukan. 
Fitria, Novita

Six Sigma Sebagai Strategi Bisnis Dalam Upaya Peningkatan Kualitas Produk

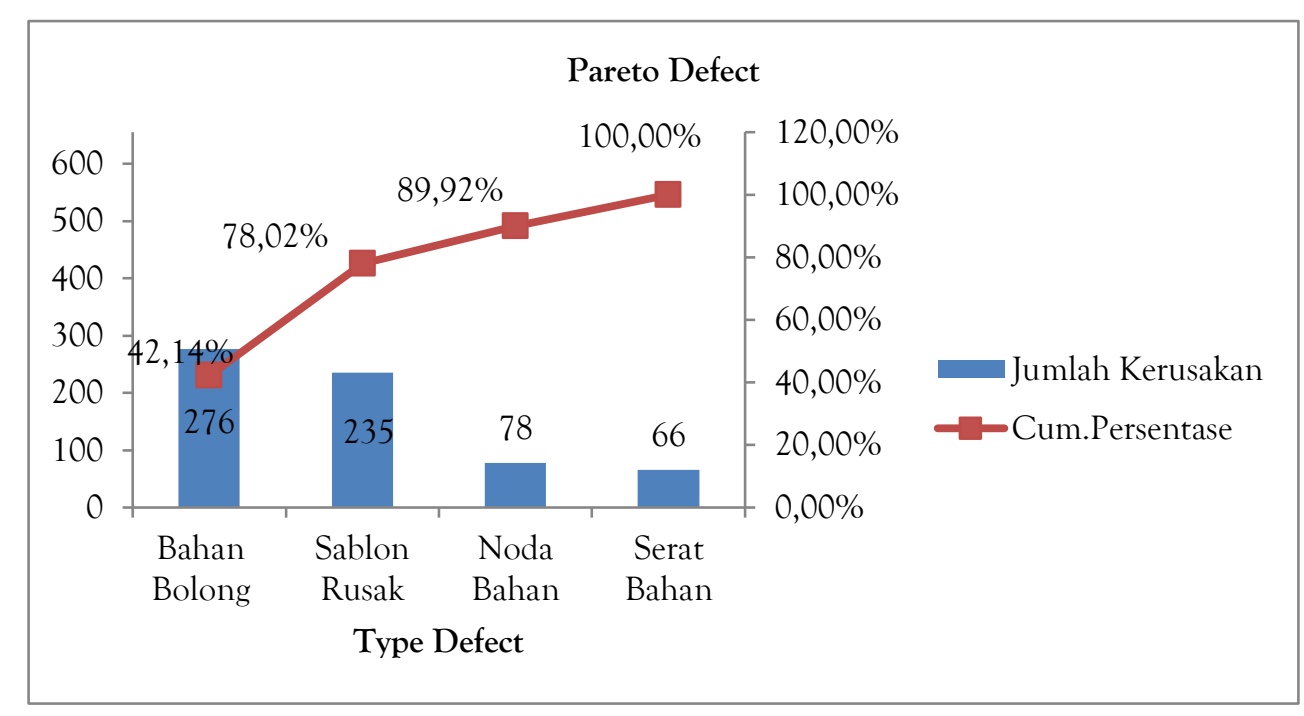

Grafik 1. Pareto Chart

Sumber: Data Diolah (2019)

Pareto chart memiliki suatu prinsip yaitu 80/20 maka pada konveksi Cindy Garment diketahui bahwa dari keseluruhan jenis cacat yang terjadi pada konveksi Cindy Garment jenis cacat bahan bolong merupakan $80 \%$ permasalahan yang terjadi pada perusahaan tersebut.

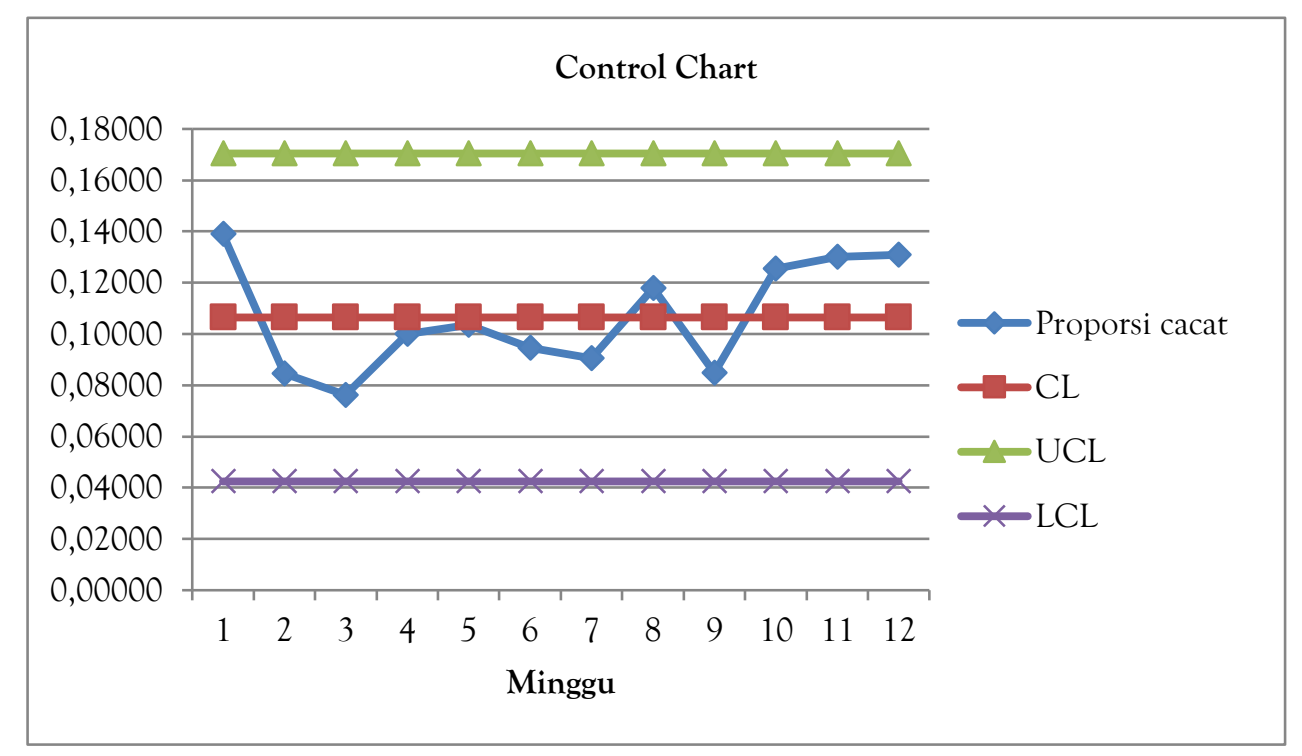

Grafik 2. Peta Kendali Periode Februari-April 2018

Sumber : Data Diolah (2019)

Berdasarkan peta kendali (control chart) di atas dapat diketahui bahwa data yang diperoleh seluruhnya berada dalam batas kendali. Proses produksi secara keseluruhan yang dilakukan oleh konveksi Cindy Garment stabil tetapi berdasarkan peta kendali tersebut dapat diketahui bahwa dalam proses produksi yang dilakukan, konveksi Cindy Garment memiliki proporsi cacat (defect) produk yang berfluktuasi atau pemborosan dalam proses produksi masih terus terjadi hal ini sangat merugikan perusahaan. Penelitian ini sejalan dengan penelitian terdahulu oleh Safrizal \& Muhajir, (2016) yang mengungkapkan bahwa tingkat kecacatan (defect) yang tinggi dapat merugikan perusahaan jika tidak dilakukan perbaikan. Perusahaan masih sangat tidak kompetitif karena berada pada level yang sangat rendah yaitu level dua sigma. 
Sejalan dengan penelitian terdahulu sebagaimana diungkapkan oleh Jirasukprasert, Garza-Reyes, Kumar, \& Lim, (2015) bahwa apabila sebuah perusahaan belum mampu mencapai level sigma enam maka perusahaan tersebut masih belum menjadi perusahaan yang kompetitif.

\section{Analyze}

Pada tahap ini tools yang digunakan yaitu fishbone diagram untuk menganalisis faktorfaktor yang menjadi penyebab kecacatan produk.

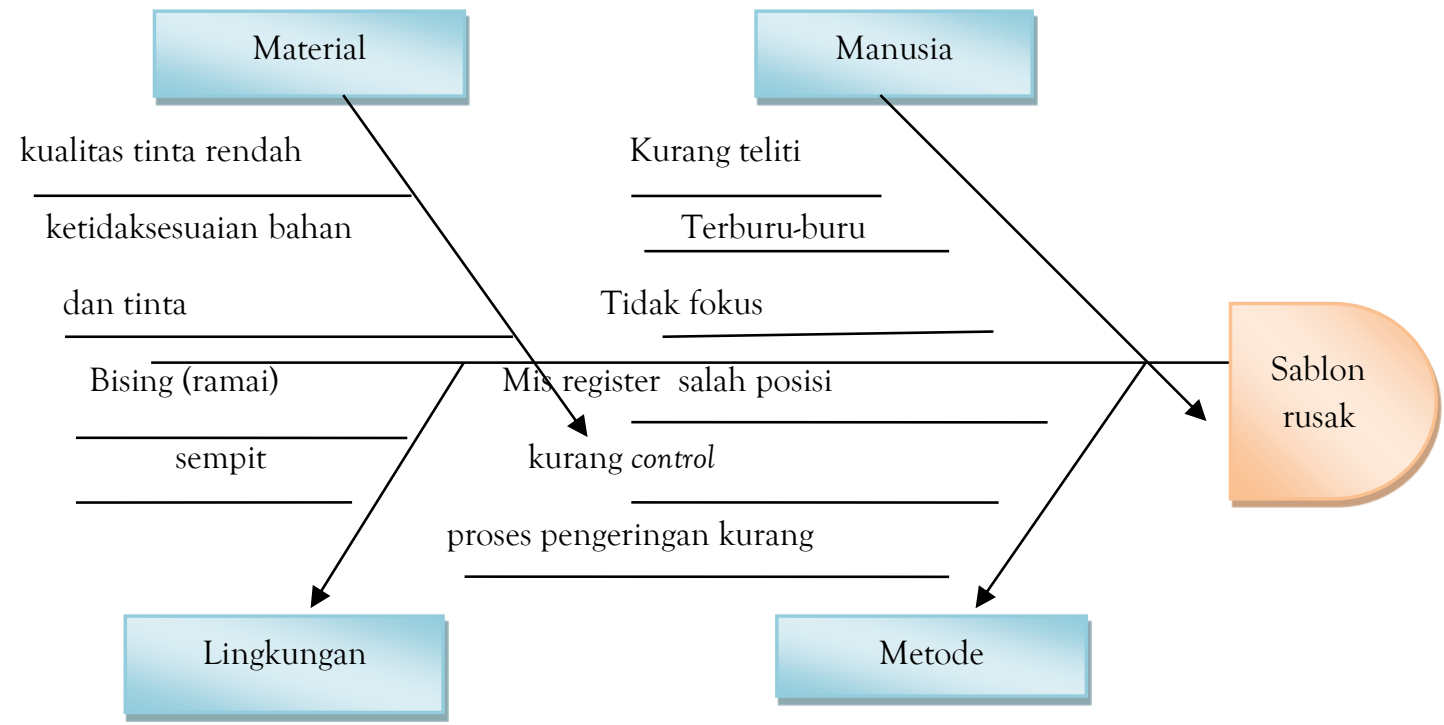

Gambar 2. Fishbone Diagram Sablon Rusak Sumber : Konveski Cindy Garment (2019)

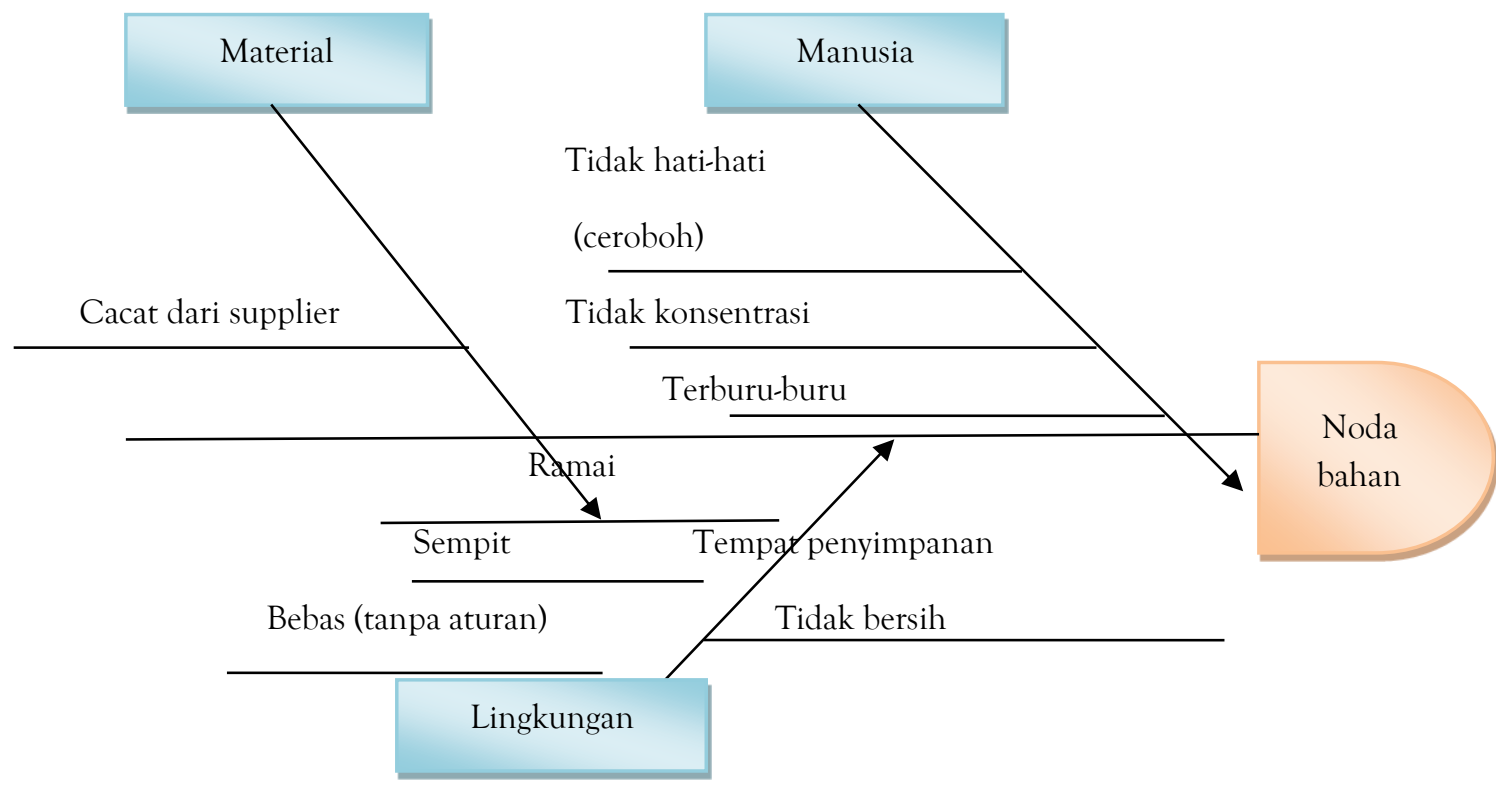

Gambar 3. Fishbone Diagram Cacat Noda Bahan Sumber : Konveksi Cindy Garment (2019) 
Fitria, Novita

Six Sigma Sebagai Strategi Bisnis Dalam Upaya Peningkatan Kualitas Produk

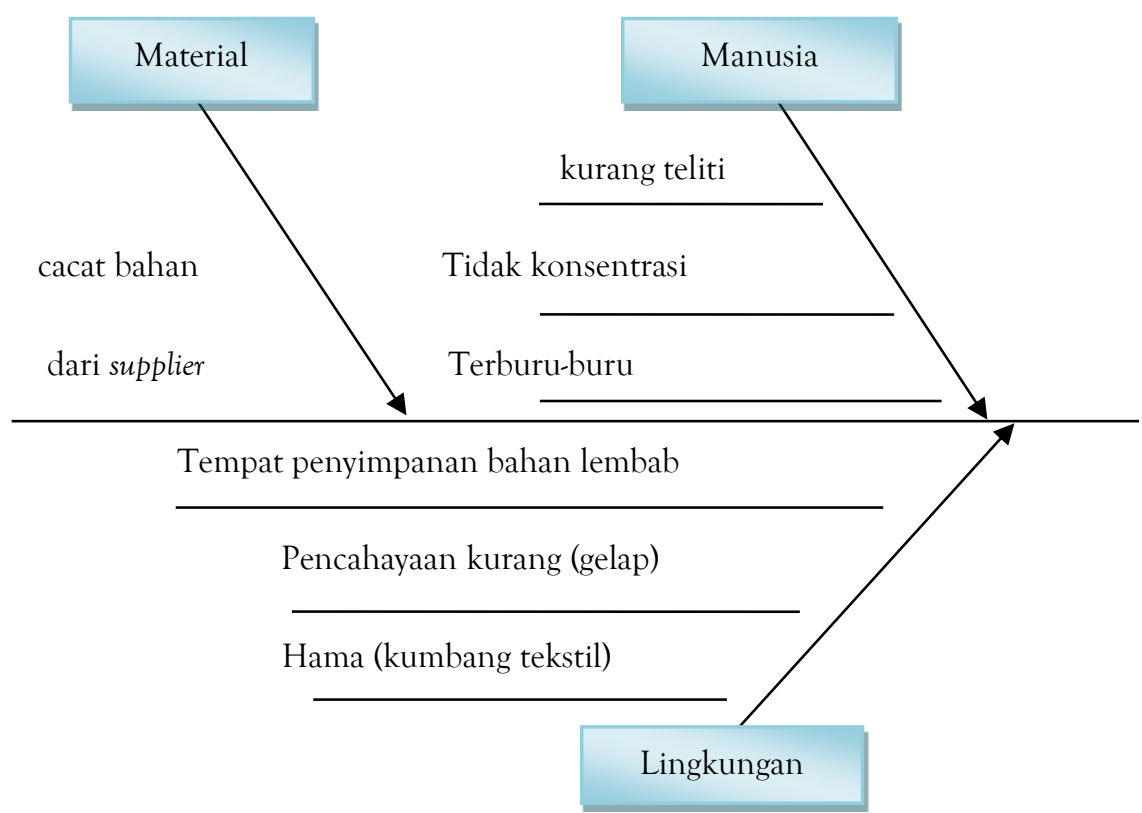

Bahan

bolong

Gambar 4. Fishbone Diagram Bahan Bolong

Sumber : Konveksi Cindy Garment (2019)

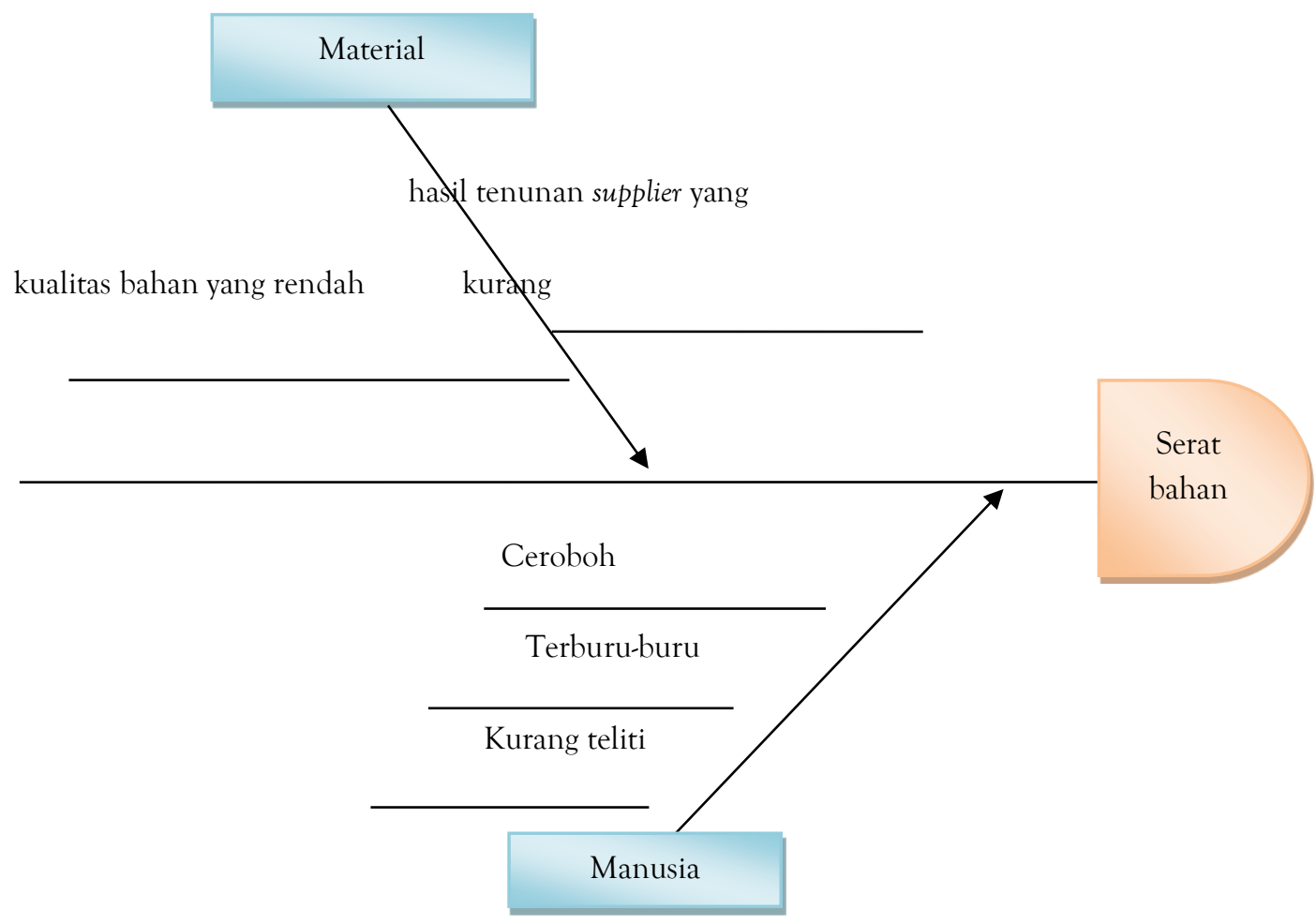

Gambar 5. Fishbone Diagram Serat Bahan

Sumber: Konveksi Cindy Garment (2019)

Berdasarkan analisis yang dilakukan dengan menggunakan fishbone diagram atau diagram sebab akibat maka dapat diketahui penyebab dari permasalahan yang terjadi. Pada konveksi Cindy Garment diketahui bahwa yang menjadi penyebab kecacatan (defect) terhadap output atau produk yang dihasilkan yaitu faktor para pekerja, material, lingkungan

Jati : Jurnal Akuntansi Terapan Indonesia, 2020 | 10 
dan metode. Fishbone diagram atau diagram sebab akibat merupakan suatu alat (tools) yang digunakan untuk memecahkan masalah. Sebagaimana diungkapkan oleh penelitian terdahulu oleh Mijajlevski, (2013) bahwa diagram sebab akibat (fishbone diagram) dikembangkan untuk mengidentifikasi faktor-faktor penyebab atau hal-hal yang mempengaruhi berjalannya suatu proses bisnis. Sehingga dengan tools diagram sebab akibat (fishbone diagram) dapat dilakukan brainstorming.

Improve

Pada tahap improve akan dilakukan tindakan perbaikan yang dapat diterapkan oleh perusahaan di masa mendatang. Berikut beberapa usulan tindakan perbaikan yang dapat diterapkan oleh konveksi Cindy Garment.

Faktor man (manusia)

Usulan perbaikan yang dapat dilakukan oleh perusahaan agar dapat meningkatkan kualitas produk yaitu perusahaan dapat memberikan pelatihan kepada para pekerja sebelum mereka melakukan pekerjaan agar dapat meningkatkan pemahaman keterampilan serta dapat menumbuhkan motivasi karyawan dalam bekerja sehingga mampu meningkatkan produktivitas perusahaan. Kemudian perusahaan dapat memberikan bonus tambahan sebagai penghargaan (reward) bagi para pekerja yang memenuhi target atau tujuan perusahaan. Perusahaan dapat menerima karyawan baru yang memiliki kompetensi dan kapasitas bekerja yang lebih cepat dan tepat.

\section{Faktor metode}

Usulan perbaikan yang dapat dilakukan untuk kesalahan metode yang dilakukan oleh para pekerja agar kesalahan tersebut tidak terjadi kembali maka setiap awal bekerja perusahaan harus melakukan pembaruan terhadap (SOP) yang ada serta memberikan penjelasan kembali kepada karyawan mengenai prosedur kerja yang ada (SOP) baik secara lisan maupun tulisan. Perusahaan juga dapat memasang kamera CCTV untuk memantau kinerja dari para pekerja. Kemudian pengeringan sablon yang tidak tepat perusahaan dapat melakukan pengeringan sablon dengan menggunakan mesin hotpress.

Faktor material

Usulan perbaikan yang dapat dilakukan yaitu perusahaan harus lebih kritis dalam memilih supplier agar bahan baku (material) yang diterima dari supplier tidak ada yang cacat (defect).

Faktor lingkungan

Perusahaan dapat memperhatikan kaidah $5 \mathrm{~S}$ (seiri, seiton, seiketsu, dan shitsuke) dimana seiri (ringkas) yaitu barang-barang yang tidak diperlakukan dapat dibuang kemudian seiton (rapi) dimana perusahaan harus membenahi dan menstandarkan tempat penyimpanan atau menata barang atau peralatan pada tempatnya seiso (resik) yaitu memelihara atau menjaga kebersihan tempat kerja (membersihkan tempat kerja agar bebas dari debu dan sampah) seiketsu (rawat) mempertahankan tempat kerja agar tetap ringkas bersih dan rapi. Dan yang terakhir yaitu shitsuke (rajin) yaitu mendisiplinkan diri sendiri hal ini dapat diwujudkan jika perusahaan mampu mensosialisasikan kaidah tersebut dengan baik kepada para pekerja. Perusahaan dapat membuat rak atau meja dorong khusus (troli) agar barang-barang yang diperlukan tertata sehingga membuat lingkungan kerja menjadi nyaman. Untuk menghindari cacat bahan bolong karena tempat penyimpanan yang gelap perusahaan dapat menggunakan atap polycarbonate. Agar ruang penyimpanan menjadi lebih terang dan dapat menyerap panas dengan baik. 
Faktor mesin

Faktor mesin bukan merupakan penyebab dari kecacatan (defect) produk yang terjadi pada konveksi Cindy Garment melainkan mesin tersebut dapat menjadi biaya bagi perusahaan yaitu biaya perbaikan dan pemeliharaan mesin. Mesin yang tidak digunakan dapat dijual dahulu agar tidak menambah cost bagi perusahaan.

Berikut adalah estimasi biaya yang akan dikeluarkan untuk melakukan perbaikan.

Tabel 3. Estimasi Biaya Perbaikan

Sumber: Data Diolah (2019)

\begin{tabular}{lll}
\hline No & \multicolumn{1}{c}{ Jenis biaya } & Estimasi biaya \\
\hline 1 & $\begin{array}{l}\text { Biaya pelatihan para pekerja : } \\
\text { Pelatihan sablon } \\
(2 \text { hari @ 6 jam) } \\
\text { Pelatihan terampil menjahit } \\
\text { Lama pelatihan 3 bulan } \\
\text { (seminggu 3 kali @ 4 jam) }\end{array}$ & \\
& Rp. 1.500 .000 \\
2 & Atap polycarbonate & Rp. 2.700 .000 \\
3 & Kamera CCTV & Rp. 3.000.000 \\
4 & Meja atau rak dorong (troli) & Rp. 2.000 .000 \\
5 & Mesin hotpress & Rp. 2.000.000 \\
& Total biaya & Rp. 11.500 .000 \\
\hline
\end{tabular}

Setelah dilakukan analisis pada tahap analyze maka selanjutnya dilakukan improve dimana pada tahap improve yang dilakukan yaitu memberikan solusi dari permasalahan yang terjadi. Penelitian ini sejalan dengan penelitian terdahulu yang dilakukan oleh Wulandari, (2018) dimana pada tahap improve dibuat usulan perbaikan untuk menanggulangi kecacatan yang terjadi pada setiap proses produksi yang dilakukan.

Control

Tahap control merupakan tahap terakhir dalam six sigma. Penting bagi perusahaan untuk mengawasi setiap proses produksi yang dilakukan karena hal ini sangat mempengaruhi kinerja perusahaan dalam mengasilkan output yang diinginkan. Jika suatu perusasaan hanya mampu membuat suatu metode baru tetapi tidak ada pengawasan secara langsung yang dilakukan maka dapat dilakukan oleh perusahaan yaitu:

Pengendalian Hasil (result control)

Dimana pengendalian hasil (result control) merupakan salah satu bentuk pengendalian yang dapat dilakukan oleh perusahaan dengan cara memberikan penghargaan (reward) bagi karyawan yang memiliki kinerja sesuai dengan yang diinginkan oleh perusahaan. Reward atau penghargaan yang dapat diberikan bisa dalam berbagai bentuk yang bernilai bagi karyawan seperti kenaikan gaji bonus keamanan kerja kesempatan pelatihan kebebasan dan hal lain yang dapat bernilai bagi karyawan.

Pengendalian Tindakan (action control)

Pengendalian tindakan yang dapat dilakukan oleh perusahaan yaitu dengan membatasi perilaku karyawan hal ini dilakukan agar karyawan lebih sulit untuk melakukan hal-hal yang seharusnya tidak dilakukan oleh karyawan. Pembatasan perilaku yang dapat dilakukan salah satunya dengan menggunakan teknologi canggih yaitu kamera CCTV yang dapat digunakan untuk memantau perilaku karyawan. 
Pengendalian personel (personel control)

Melakukan seleksi kepada karyawan baru yang akan bekerja dimana seleksi tersebut dilakukan dengan cara melihat kemampuan (skill) yang dimiliki oleh karyawan tersebut kemudian perusahaan dapat memberikan pelatihan kepada karyawan sesuai dengan kebutuhan perusahaan.

Pengendalian budaya (culture control)

Salah satu bentuk pengendalian budaya yang dapat dilakukan oleh konveksi Cindy Garment yaitu dengan menanamkan sikap disiplin dan sikap kerjasama yang baik antara karyawan dengan atasan seperti disiplin waktu mulai dar jam kerja jam istirahat sampai jam pulang atau selesai bekerja. Jika hal ini dilakukan dengan konsisten oleh perusahaan maka sikap disiplin tersebut akan menjadi budaya bagi perusahaan.

Pada tahap control yang dilakukan dalam penelitian ini yaitu melakukan pengawasan terhadap tindakan yang akan dilakukan agar kesalahan yang lama tidak terulang kembali. Penelitian ini sesuai dengan penelitian terdahulu yang dilakukakan Safrizal \& Muhajir, (2016) bahwa tahap terakhir yaitu menekan atau mencegah terjadinya kesalahan yang lampau.

\section{KESIMPULAN}

Cacat yang paling potensial pada konveksi Cindy Garment yaitu bahan bolong dengan persentase cacat sebesar $42,14 \%$. Perusahan masih berada pada level dua sigma dengan DPMO sebesar 106.416,66. Faktor penyebab dari permasalahan tersebut yaitu para pekerja, material, metode dan lingkungan. Hal ini sangat merugikan perusahaan jika tidak dilakukan tindakan perbaikan yang tepat. Perusahaan dapat melakukan mangement control yang baik seperti melakukan pengendalian hasil, pengendalian tindakan, pengendalian personel dan pengendalian budaya.

\section{DAFTAR PUSTAKA}

Alfian huda, sri widiyanesti. (2018). Analisis Pengendalian Kualitas Proses Pengelasan (Welding ) Dengan Pendekatan Six Sigma Pada Proyek Pt. Xyz. (2016), 1-12.

Antony, J., Gijo, E. V., Kumar, V., \& Ghadge, A. (2016). A multiple case study analysis of Six Sigma practices in Indian manufacturing companies. International Journal of Quality and Reliability Management, 33(8), 1138-1149. https://doi.org/10.1108/IJQRM-10-2014-0157

Damayanti, A. R. (2017). Pengendalian Kualitas Produk Dengan Metode Six Sigma. Universitas Pesantren Tinggi Darul 'Ulum Jombang.

F. Hutami, R. R., \& Yunitasari, C. (2017). Analisis Pengendalian Kualitas Produk Dengan Metode Six Sigma Pada Perusahaan Percetakan Pt. Okantara. Kinerja, 20(1), 81. https://doi.org/10.24002/kinerja.v20i1.699

Gaspersz, V. (2011). Total Quality Management Untuk Praktisi Bisnis dan Industri. Bogor: Vinchristo Publication.

Jirasukprasert, P., Garza-Reyes, J. A., Kumar, V., \& Lim, M. K. (2015). A six sigma and dmaic application for the reduction of defects in a rubber gloves manufacturing process. International Journal of Lean Six Sigma, 5(1), 2-22. https://doi.org/10.1108/IJLSS-03-2013-0020

Kontan.co.id. (2019). Tantangan bagi industri garmen dan tekstil di tahun 2019.

Mijajlevski, A. (2013). the Six Sigma Dmaic Methodology in Logistics. (November), 227-232. Retrieved from http://logic.sf.bg.ac.rs/wp-content/uploads/Papers/ID-41.pdf

Nakhai, B., \& Neves, J. S. (2009). The challenges of six sigma in improving service quality. International Journal of Quality and Reliability Management, 26(7), 663-684. https://doi.org/10.1108/02656710910975741 
Safrizal, \& Muhajir. (2016). Jurnal Manajemen Dan KeuanganPengendalian Kualitas Dengan Metode Six Sigma. Jurnal Manajemen Dan Keuangan, Vol 5(2), h 1-12.

Sirine, H., Kurniawati, E. P., Pengajar, S., Ekonomika, F., Bisnis, D., \& Salatiga, U. (2017). Pengendalian Kualitas Menggunakan Metode Six Sigma (Studi Kasus pada PT Diras Concept Sukoharjo). AJIE-Asian Journal of Innovation and Entrepreneurship,02(03),24773824.Retrievedfrom http://www.dirasfurniture.com

Sugiyono. (2016). Metode Penelitian Kuantitatif, Kualitatif, dan REDD. Bandung: Alfabeta.

Widiatmoko, D. A., \& Segoro, W. (2015). Aplikasi 6 Sigma Dalam Menurunkan Malfunction Defect Di Pengetesan Elektrikal (Ac Transient Test) Pada Tahapan Pengembangan Produk Blu-Ray Disc Player (Studi Kasus Di Perusahaan Manufaktur Elektronik). V(3), 400-417.

Wulandari, I. (2018). Penerapan Metode Pengendalian Kualitas Six Sigma Pada Heyjacker Company. $4988,222-241$. 